\section{Promoting Germination in Ornamental Palm Seeds through Dormancy Alleviation}

\author{
Hector E. Pérez ${ }^{1}$
}

\begin{abstract}
Additional index words. Arecaceae, embryo, imbibition, morpho-physiological, operculum, stratification

Summary. Delayed and inconsistent seed germination often hampers commercial production of palms (Arecaceae). Such sporadic germination is commonly due to seed dormancy. Mature, freshly shed seeds of palms typically display a combination of underdeveloped embryos (morphological dormancy) and the inability of developing embryos to rupture covering structures (physiological dormancy). Fruit and seedcoats are capable of imbibing water. Therefore, dormancy due to waterimpermeable fruit or seedcoats (physical dormancy) does not occur. Removal of embryo covering structures, such as the pericarp and operculum, followed by

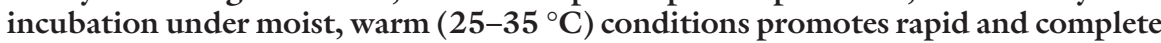
germination. Complete burial in soil promotes germination of seeds in intact fruit of loulu palm (Pritchardia remota).
\end{abstract}

W ith over 2000 species, the palm family (Arecaceae) is diverse (Uhl and Dransfield, 1987). This diversity is manifest in numerous growth forms, textures, colors, and cultivation requirements. Palms are used in various interior and exterior landscape settings because of their assortment of features that add a touch of elegance and stimulate the senses. There is a high demand for palms in the trade. For example, yearly sales of ornamental palms in Florida reached \$220 million (U.S. Department of Agriculture, 2007). When used, palms typically represent the largest dollar investment in plant material for landscaping projects (H.E. Pérez, personal observation).

Although a few palms are amenable to propagation through division of rhizomes, offshoots, or tissue culture, the vast majority of landscape palms are propagated by seeds. However, commercial production of many palm species is hampered by delayed and inconsistent germination. Such sporadic germination is often due to seed dormancy mechanisms. Therefore, the intent of this article is to review dormancy mechanisms in palms and to communicate methods to promote germination in this valuable group of plants.

\section{Classes of seed dormancy}

From a functional perspective, seed dormancy is a trait that prevents

University of Florida, Department of Environmental Horticulture, P.O. Box 110675, Gainesville, FL 32611-0675

${ }^{1}$ Corresponding author. E-mail: heperez@ufl.edu. germination when conditions are suitable for germination but not for seedling establishment (Fenner and Thompson, 2005), for example, in a sudden warm period during an otherwise cold winter with frequent freezes. Baskin and Baskin (2004) consider seeds to be dormant if freshly matured, viable seeds do not germinate in about 4 weeks over a range of environmental conditions. Moreover, five classes of dormancy have been proposed. These include: physical, physiological, morphological, morpho-physiological, and combinational (Baskin and Baskin, 2001, 2004; Fenner and Thompson, 2005).

According to Baskin and Baskin (2001), seeds with physical dormancy possess fruit coats (pericarps) or seedcoats (testa) that are water impermeable. The nature of the impermeability may be due to multiple layers of tightly spaced, thickwalled cells in the pericarp and testa, the presence of waxes, lignins, and pectins, or a combination of these factors. Seeds with physiological dormancy possess embryos that cannot generate sufficient force to rupture embryo-covering structures, such as endosperm, testa, or pericarps. Mature seeds with underdeveloped embryos that need more time to grow before germination can occur are morphologically dormant. Finally, seeds may possess combinations of dormancy. For example, some seeds possess morphological and physiological (morpho-physiological) or physical and physiological (combinational) dormancy. Physiological and morpho-physiological dormancy can be broken down further into different levels of dormancy, which are based on requirements for dormancy alleviation (Baskin and Baskin, 2001, 2004).

\section{Palm fruit and seed morphology}

Generally, palm fruit consist of three layers, collectively referred to as the pericarp (Uhl and Dransfield, 1987). The exocarp, or outer covering, is usually smooth, although the exocarp of some species may possess hairs, warts, or prickles. The mesocarp is usually fleshy or fibrous and may be dry at fruit shedding. The inner fruit layer, or endocarp, is very thick and woody in most species. Fruit typically consist of one large seed enclosed within the endocarp (Uhl and Dransfield, 1987). Palm seeds may possess a relatively thick endocarp and testa (Figs. 1 and 2). A germination lid, or operculum, may be observed on the testa or endocarp of some species. The small, usually cylindrical embryo is found under the operculum (Fig. 3). For the most part, palm seeds are shed with considerable amounts of hard endosperm (Uhl and Dransfield, 1987).

\section{Seed dormancy in palms}

Although seeds of a few palm species such as areca palm (Chrysalidocarpus lutescens), sabal palm (Sabal palmetto), washington palm (Washingtonia robusta), and date palm (Phoenix dactylifera) complete germination in $28 \mathrm{~d}$ or less (Broschat and Donselman, 1986; Broschat and Meerow, 2000; Brown, 1976; Loomis, 1958; von Fintel et al., 2004; Wagner, 1982),

\begin{tabular}{llll}
\hline $\begin{array}{l}\text { Units } \\
\begin{array}{l}\text { To convert U.S. to SI, } \\
\text { multiply by }\end{array}\end{array}$ & U.S. unit & SI unit & $\begin{array}{l}\text { To convert SI to U.S., } \\
\text { multiply by }\end{array}$ \\
\hline 2.54 & inch $(\mathrm{es})$ & $\mathrm{cm}$ & 0.3937 \\
25.4 & inch $(\mathrm{es})$ & $\mathrm{mm}$ & 0.0394 \\
1 & micron & ${ }^{\mu \mathrm{M}}$ & 1 \\
$\left({ }^{\circ} \mathrm{F}-32\right) \div 1.8$ & ${ }^{\circ} \mathrm{F}$ & ${ }^{\circ} \mathrm{C}$ & $\left(1.8 \times{ }^{\circ} \mathrm{C}\right)+32$
\end{tabular}



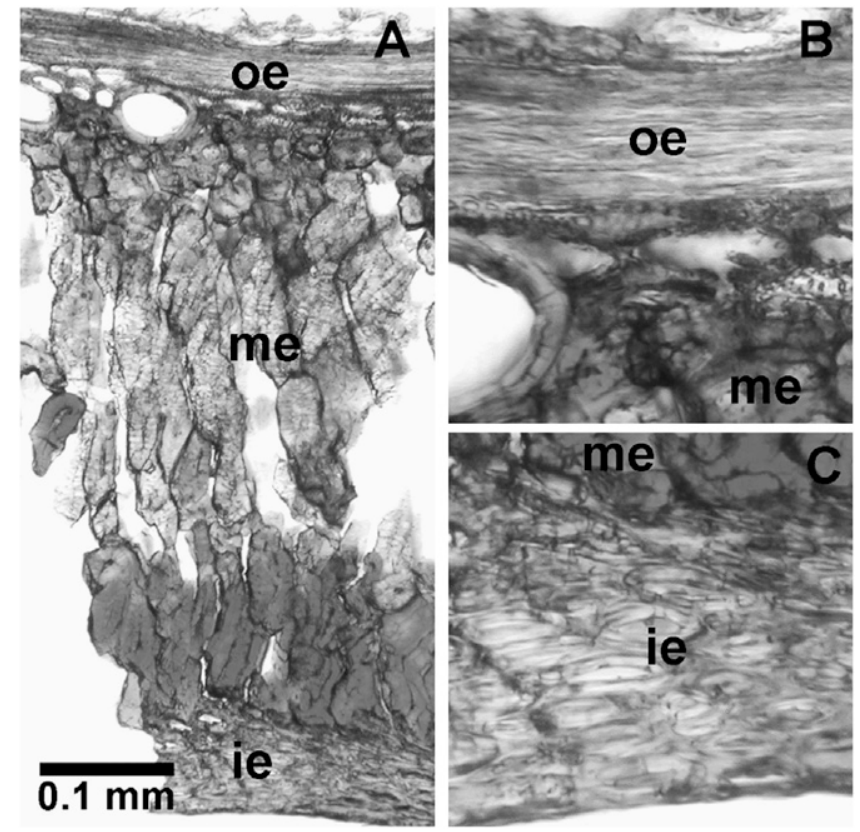

Fig. 1. Anatomy of mature loulu palm (Pritchardia remota) endocarp. (A) Note the multiple layers comprising the endocarp. The middle endocarp (me) is thick and composed of thick-walled, pitted sclerids with lignin deposits. (B) and (C) are details of the outer (oe) and inner (ie) endocarp, respectively. The oe and ie are composed of tangentially stretched cells with some lignin deposits. Tissues were stained with phloroglucinol. Slides viewed and images captured at $\times 6.3$ in (A) and $\times 16$ in $(B)$ and $(C)$. All sections are $30 \mu \mathrm{M}$ (microns); $1 \mathrm{~mm}=\mathbf{0 . 0 3 9 4}$ inch.
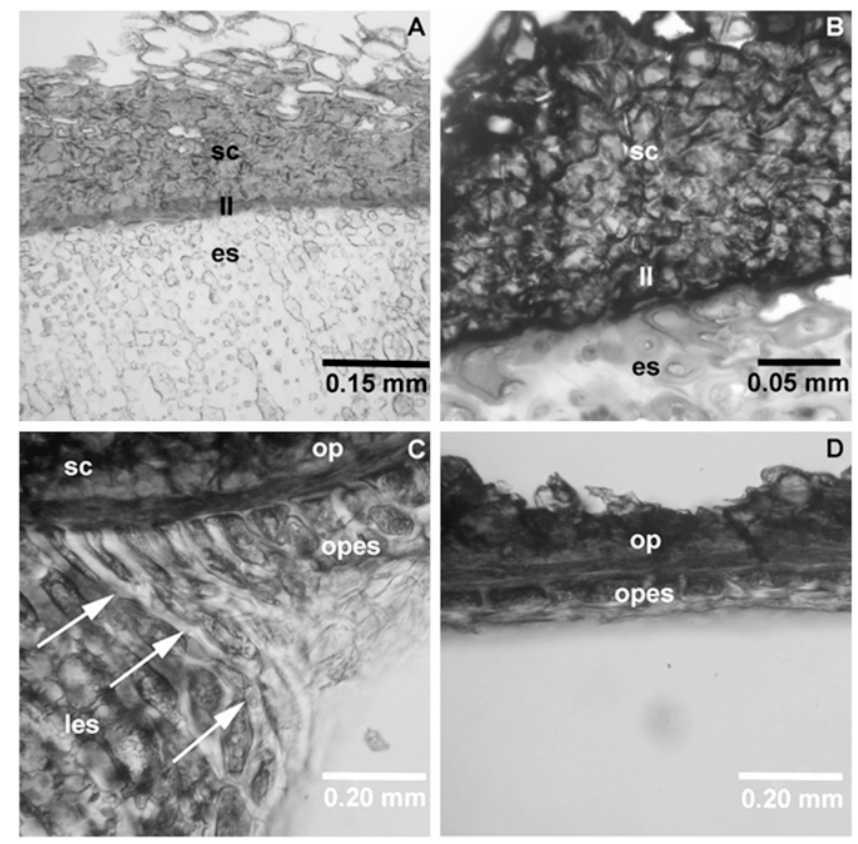

Fig. 2. Loulu palm (Pritchardia remota) seedcoat and operculum. Seed coats (sc) stained with phloroglucinol (A) or toluidene blue (B) display lignification of the cells and a prominent lignin layer (11). The endosperm (es) is composed of thickwalled cells. Seed coat sections are $10 \mu \mathrm{M}$ (microns). Thick sections $(50 \mu \mathrm{M})$ of the lateral (C) and central (D) part of the operculum. Note that the central part of the operculum is subtended by a layer of endosperm one to two cell layers thick, while the lateral portion has thicker underlying endosperm layers. The operculum is an extension of the seedcoat. Opes $=$ operculum endosperm, op $=$ operculum, $s c=$ seedcoat (testa), and es = endosperm. Arrows in (D) denote zone where operculum breaks free from the seedcoat during displacement by the growing embryo. Magnification $\times 40$ in (A) and $\times 63$ in (B); $1 \mathrm{~mm}=0.0394$ inch. the majority of species germinate slowly. For example, germination commenced about 5 weeks after sowing and continued sporadically over the next 17 weeks in fruit of loulu palm (Pritchardia remota) (Pérez et al., 2008). Koebernik (1971) lists 126 species that completed germination more than $100 \mathrm{~d}$ after sowing. Likewise, Tomlinson (1990) estimated that $25 \%$ or more of all palm species required more than $100 \mathrm{~d}$ to germinate. Finally, Orozco-Segovia et al. (2003) reported that many palms began germinating about 17 weeks after shedding, suggesting that a period of dormancy may be present.

It is often assumed that the thick endocarp and testa of many palms are impermeable to water (OrozcoSegovia et al., 2003). For example, Moussa et al. (1998) suggested that the thick pericarps of doum palm (Hyphaene thebaica) are water impermeable. Yet, these authors provided no evidence that imbibition is blocked due to the pericarp. On the contrary, imbibition may occur in palm seeds, albeit relatively slowly (Ehara et al., 2001; Robertson and Small, 1977; Wood and Pritchard, 2003) or rapidly (Brown, 1976), suggesting that the pericarp or testa are permeable. Pérez et al. (2008) demonstrated that endocarps, seeds, and embryos of loulu palm ( $P$. remota) become hydrated to similar levels whether endocarp or testa are mechanically abraded or not. Imbibition occurred, but at a slow rate in all treatments. Moreover, endocarp and testa anatomy in various palms species did not resemble the anatomy typically found in seeds of nonpalm species with water-impermeable coats (Baskin and Baskin, 2001; Pérez et al., 2008). Therefore, physical and combinational (physical + physiological) dormancy are not present in palm seeds (Baskin and Baskin, 2001).

A distinguishing feature of some palm seeds is their small, late-maturing embryo (Uhl and Dransfield, 1987). These underdeveloped embryos require further growth outside of the seed and endocarp before germination is complete; hence, they are considered morphologically dormant (Baskin and Baskin, 2004). Analysis of data presented by Wood and Pritchard (2003) showed that embryos of bottle palm (Hyophorbe lagenicaulis) are 

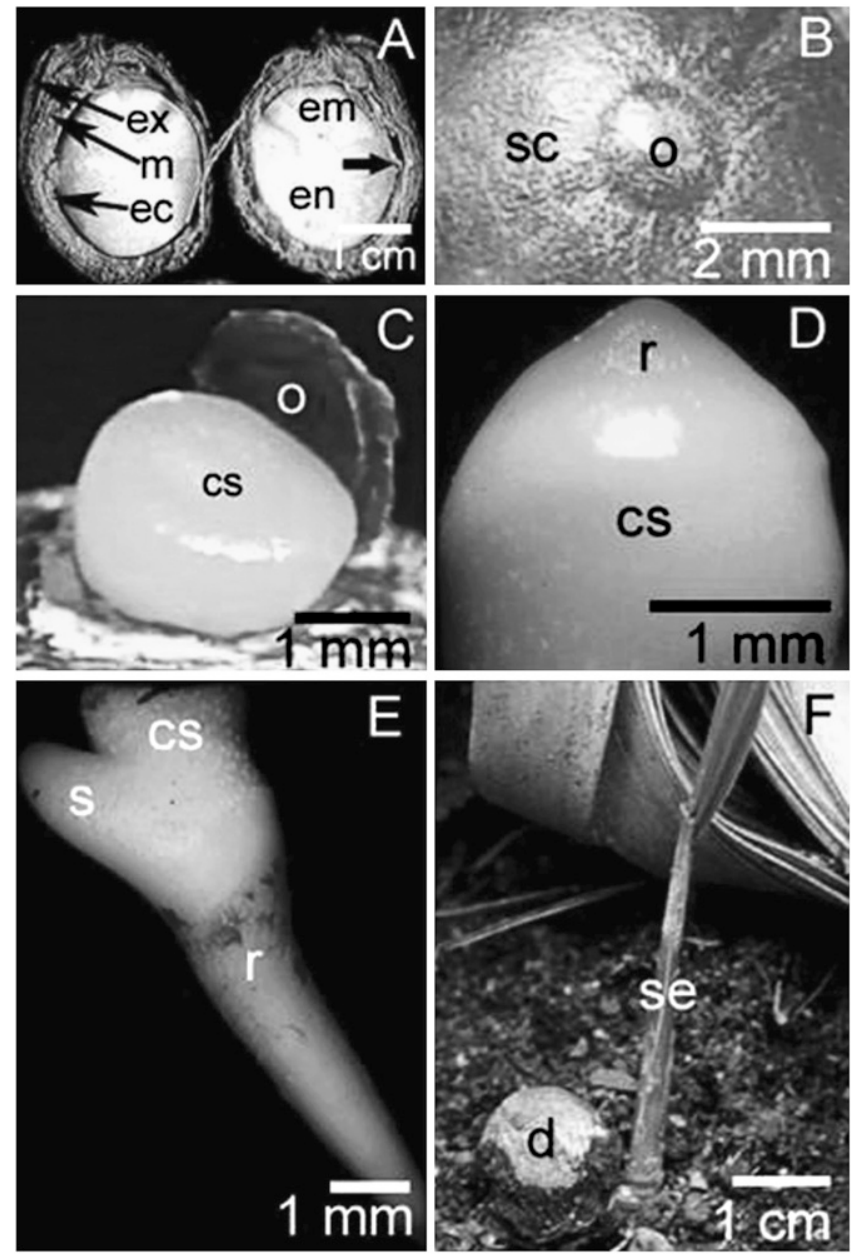

Fig. 3. Fruit and seed morphology of loulu palm (Pritchardia remota). (A) Crosssection of freshly shed loulu palm fruit. The pericarp consists of the exocarp (ex), mesocarp (m), and endocarp (ec). The seedcoat (block arrow), endosperm (en), and embryo (em) also are visible. (B) Detail of seedcoat (sc) showing intact operculum (o). (C) Cotyledonary stalk (cs) of loulu palm pushing operculum aside. Note the lack of a protruding radicle. The radicle begins to protrude between 7 and $14 \mathrm{~d}$ after emergence of cotyledonary stalk through the endocarp. (D) Radicle (r) of loulu palm protruding through the cotyledonary stalk. (E) The elongating radicle and emerging shoot (s) are visible about 3 weeks after emergence of the cotyledonary stalk from the seed. (F) Young loulu palm seedling (se). Note that the seedling is still attached to the fruit, a drupe (d). However, the exocarp and mesocarp have disintegrated and only the endocarp remains with the seed inside; $1 \mathrm{~mm}=0.0394$ inch, $1 \mathrm{~cm}=0.3937$ inch.

$10.3 \%$ the length of seeds at fruit shedding. Furthermore, the cotyledonary stalk, which contains the shoot and root meristems, must continue growing past the testa before radicle protrusion occurs. The small embryos of loulu palm (P. remota) are about 4.0 $\mathrm{mm}$ in length or about $30 \%$ the length of seeds at shedding. To break through the testa and eventually produce a radicle, the embryos must grow about 1.5 and 3.0 times their initial length, respectively (Pérez et al., 2008). Continued embryo growth before radicle protrusion has been documented for palms such as the spineless sago palm (Metroxylon sagu) (Ehara et al., 1998), common bertam palm (Eugeissona tristis) (Fong, 1978), another species of loulu palm (Pritchardia kaalae) (Hodel, 1977), and african oil palm (Elaeis guineensis) (Hussey, 1958).

Restriction of embryo growth is considered to be one cause of physiological dormancy (Baskin and Baskin, 2001). Growth restriction may be the result of embryo-covering structures such as opercula (germination lid on the testa or endocarp), endosperm, testa, and endocarp. Opercula provide mechanical resistance to embryo elongation in african oil palm (Hussey, 1958). In de-operculated seeds, embryos commenced elongation after $4 \mathrm{~d}$ at $30{ }^{\circ} \mathrm{C}$. However, intact seeds failed to germinate for 6 months. Similarly, embryo elongation in needle palm (Rhapidophyllum hystrix) was controlled by the operculum (Carpenter and Cornell, 1993). Furthermore, pericarps may mechanically restrict growth of the embryo (Baskin and Baskin, 2001). Removal of the entire pericarp (Briceño and Maciel, 2004) or fleshy mesocarp (Broschat, 1998; Broschat and Donselman, 1986) significantly improved germination in a variety of palms.

Removing the pericarp of loulu palm $(P$. remota) and then incubating seeds under moist, warm $\left(25-35^{\circ} \mathrm{C}\right)$ conditions, or warm stratification, alleviated dormancy and significantly promoted germination rate and percentage (Pérez et al., 2008). For instance, the time taken for $50 \%$ of seeds to germinate ranged between 2 and 5 weeks, whereas intact fruit only germinated to about $20 \%$ over 22 weeks. Germination of intact fruit and seeds was restricted at $15{ }^{\circ} \mathrm{C}$. Furthermore, germination climbed to $84 \%$ after 7 d for loulu palm ( $P$. remota) seeds without opercula. Over the same time period, intact seeds only germinated to about $8 \%$ (Pérez et al., 2008). Germination speed and percentage improved in seeds of the european fan palm (Chamaerops humilis) when the exocarp and mesocarp were removed and the endocarp was weakened through scarification. Germination in this species occurred at constant 20 or $25^{\circ} \mathrm{C}$, or alternating $15 / 25^{\circ} \mathrm{C}$, but not at $15{ }^{\circ} \mathrm{C}$ (González-Benito et al., 2006).

Seed dormancy is a common occurrence in palms from various origins (Baskin and Baskin, 2001; GonzálezBenito et al., 2006; Orozco-Segovia et al., 2003). Moreover, morphophysiological dormancy is the most common class of dormancy in Arecaceae (Baskin and Baskin, 2001; Pérez et al., 2008). Using loulu palm ( $P$. remota) as a model, it is concluded that physiological dormancy must be alleviated before morphological dormancy (Pérez et al., 2008). As physiological dormancy is broken under warm, moist conditions the growth potential of the embryo increases and 
the embryo eventually dislodges the operculum and ruptures the endocarp. Once free of the endocarp, the embryo continues development and produces a radicle. This process can take in excess of $100 \mathrm{~d}$ for some palm species (Koebernik, 1971; OrozcoSegovia et al., 2003; Tomlinson, 1990) and may be attributed to slow imbibition, multiple restraint mechanisms, and underdevelopment of the embryo.

\section{Alleviating dormancy and promoting germination}

Seed dormancy, although widespread in the palm family and advantageous from an ecological perspective, can frustrate palm growers and enthusiasts. Waiting for seeds to germinate may add costs and inefficiencies to the production process. However, knowing the class of seed dormancy found in seeds can facilitate production and eliminate unnecessary treatments. Burying mature intact palm fruit in soil and then maintaining warm, moist conditions will produce some dormancy break and germination (Pérez et al., 2008) with little up front effort. Of course, this system requires more time and effort later in the production cycle as germination checks are frequently needed and nongerminated seeds must be reburied. Because most palms will possess morpho-physiological dormancy, the removal of embryo-covering structures will promote germination rate and percentage. To enhance germination, the fleshy mesocarp and/or endocarp should be removed (Pérez, 2005 ) and seeds should be warm stratified (incubation at $25-35{ }^{\circ} \mathrm{C}$ in moist media) for about 4 weeks. Germination can be enhanced further through removal of the operculum if present. If the operculum is removed, then seeds should be dusted with thiophanate-methyl fungicide before warm stratification (Pérez et al., 2008). Germination checks should be conducted regularly for warm-stratified seeds and any seedlings should be potted up and then acclimatized to higher light levels if necessary.

\section{Literature cited}

Baskin, C.C. and J.M. Baskin. 2001 Seeds: Ecology, biogeography, and evolution of dormancy and germination. Academic Press, San Diego, CA.

Baskin, J.M. and C.C. Baskin. 2004. A classification system for seed dormancy. Seed Sci. Res. 14:1-16.

Briceño, A. and N. Maciel. 2004. Efectos de la madurez del fruto, escarificación de semilla y temperatura de siembra en la emergencia de Sabal mauritiiformis. Proc. Interamer. Soc. Trop. Hort. 48:184-188.

Broschat, T.K. 1998. Endocarp removal enhances Butia capitata (Mart.) Becc. (pindo palm) seed germination. HortTechnology 8:586-587.

Broschat, T.K. and A. Meerow. 2000. Ornamental palm horticulture. University Press of Florida, Gainesville, FL.

Broschat, T.K. and H. Donselman. 1986. Factors affecting storage and germination of Chrysalidocarpus lutescens seeds. J. Amer. Soc. Hort. Sci. 111:872-877.

Brown, K.E. 1976. Ecological studies of the cabbage palm, Sabal palmetto. III: Seed germination and seedling establishment. Principes 20:98-115.

Carpenter, W.J. and J.A. Cornell. 1993. Embryo cap removal and high-temperature exposure stimulate rapid germination of needle palm seeds. HortScience 28:904-907.

Ehara, H., C. Komada, and O. Morita. 1998. Germination characteristics of sago palm seeds and spine emergence in seedlings produced from spineless palm seeds. Principes 42:212-217.

Ehara, H., O. Morita, C. Komada, and M. Goto. 2001. Effect of physical treatment and presence of the pericarp and sarcotesta on seed germination in sago palm (Metroxylon sagu Rottb.). Seed Sci. Technol. 29:83-90.

Fenner, M. and K. Thompson. 2005. The ecology of seeds. Cambridge University Press, Cambridge, UK.

Fong, F.W. 1978. Mode of germination in Eugeissona tristis Griff. Principes 22:74-76.

González-Benito, M.E., M. HuertasMicó, and F. Pérez-García. 2006. Seed germination and storage of Chamaerops humilis (dwarf fan palm). Seed Sci. Technol. 34:143-150.
Hodel, D. 1977. Notes on embryo culture of palms. Principes 21:103-108.

Hussey, G. 1958. An analysis of the factors controlling the germination of the seed of the oil palm, Elaeis guineensis (Jacq.). Ann. Bot. (Lond.) 22:259-286.

Koebernik, J. 1971. Germination of palm seed. Principes 15:134-137.

Loomis, H.F. 1958. The preparation and germination of palm seeds. Principes 2:98-102.

Moussa, H., H.A. Margolis, P.A. Dubé, and J. Odongo. 1998. Factors affecting the germination of doum palm (Hyphaene thebaica Mart.) seeds from the semi-arid zone of Niger, West Africa. For. Ecol. Mgt. 104:27-41.

Orozco-Segovia, A., A.I. Batis, M. RojasAréchiga, and A. Mendoza. 2003. Seed biology of palms: A review. Palms 47:7994.

Pérez, H.E. 2005. Rapid excision of Pritchardia embryos. Palms 49:36-39

Pérez, H.E., R.A. Criley, and C.C. Baskin. 2008. Promoting germination in dormant seeds of Pritchardia remota (Kuntze) Beck., an endangered palm endemic to Hawaii. Nat. Areas J. 28:251-260.

Robertson, B.L. and J.G. Small. 1977. Germination of Jubaeopsis caffra seeds. Principes 21:114-122.

Tomlinson, P.B. 1990. The structural biology of palms. Clarendon Press, Oxford, UK.

Uhl, N. and J. Dransfield. 1987. Genera palmarum: A classification of palms based on the work of Harold E. Moore, Jr. Liberty Hyde Bailey Hortorium and International Palm Soc, Ithaca, NY.

U.S. Department of Agriculture. 2007. Pest alert red palm mite: Raoiella indica Hirst. 15 Oct. 2008. <http://www.aphis. usda.gov/publications/plant_health/ content/printable_version/pa_rpm72007.pdf>.

von Fintel, G.T., P. Berjak, and N.W. Pammenter. 2004. Seed behaviour in Phoenix reclinata Jacquin, the wild date palm. Seed Sci. Res. 14:197-204.

Wagner, R.I. 1982. Raising ornamental palms. Principes 26:86-101.

Wood, C.B. and H.W. Pritchard. 2003. Germination characteristics of fresh and dried Hyophorbe lagenicaulis seeds. Palms 47:45-50. 